\title{
24-epibrassinolide mediated regulation of endogenous contents of auxins, abscisic acid, lipids and sugars in Brassica juncea $\mathrm{L}$. under copper stress
}

\author{
Harpreet Kaur ${ }^{1}{ }^{*}$, Renu Bhardwaj ${ }^{1}$ and Ashwani Kumar Thukral ${ }^{1}$ \\ ${ }^{1}$ Department of Botanical and Environmental Sciences, Guru Nanak Dev University, Amritsar-143005, Punjab, \\ India
}

\begin{abstract}
Brassinosteroids (BRs) role in increasing plant tolerance to various abiotic stresses has been a well established fact. In the present investigation, we evaluated the effect of seed pre-soaking treatment of 24epibrassinolide (24-EpiBR) on the soil Cu(II) stress tolerance of 30-day old Brassica juncea L. plants. It increases the ability of plants to survive under stress conditions by modulating the endogenous content of various plant growth regulators and other biomolecules. We observed that the application of 24-EpiBR improved the shoot weight and root weight of the plants under $\mathrm{Cu}(I I)$ stress. Improvement in the content of various parameters when $\mathrm{Cu}(\mathrm{II})$ was supplemented with 24-EpiBR such as sugars (glucose and sucrose); lipids (phospholipids, total sterols and esterified sterols) and plant growth regulators (abscisic acid and auxins), further proved the role of 24-EpiBR in stress amelioration. It reduced the cellular damage by reactive oxygen species (ROS) generated by $\mathrm{Cu}(\mathrm{II})$ as evident by the reduction in malondialdehyde (MDA) content with its application under $\mathrm{Cu}(\mathrm{II})$ stress. Our study has given a further insight into the functions of 24-EpiBR in increasing plant survival under heavy metal stress in a more elaborate way.
\end{abstract}

Keywords: 24-epibrassinolide, copper, auxins, abscisic acid, lipids, sugars

\section{Introduction}

$\mathrm{Cu}$ is an essential micronutrient required for the normal growth of plants as it is a component of various enzymes and proteins such as superoxide dismutase, cytochrome oxidase, polyphenol oxidase, amino oxidase and plastocyanin etc. But, at high concentrations, it disturbs the metabolic processes and inhibits the growth processes of plants. $\mathrm{Cu}$ concentration has increased in the environment due to industrial processes such as mining and smelting; its use as a pesticide (Bordeaux mixture); municipal, industrial and agricultural waste disposal etc. [1,2]. Excess $\mathrm{Cu}$ in the environment leads to the adverse effects on plant growth; alters the activities of various important enzymes which are involved in the normal plant metabolic pathways; inhibits photosynthetic electron transport; affects chloroplast integrity and composition of plastid membrane [3]. The adverse effects of $\mathrm{Cu}$ when present in excess have led the scientists to focus their research on its toxicity to various living systems. Excess $\mathrm{Cu}$ disturbs the electron movement in photosystem I and II and leads to the generation of superoxide radicals that further give rise to the hydroxyl radicals. Peroxidative chain reactions started by these ROS affect membrane lipids and disintegrate cell membranes [4].

Auxins influence many processes in plants during a plant life cycle such as lateral root formation, tropism, pattern formation at the time of embryogenesis and vascular pattering. At the cellular level they control the division of cells, their expansion and differentiation [5]. For optimum growth of plants, indole acetic acid level is highly controlled by regulating its biosynthesis, transport and interconversion of its inactive and active forms [6]. Auxin homeostasis is affected by various types of stresses such as mechanical damage, metal stress, drought, salinity, wounds, cold etc., which further affects the plant growth and development [7,8].

Abscisic acid is a phytohormone and plays important role during seed development and seed dormancy. Along with it, it is a stress hormone and acts as signalling molecule in various environmental stresses such as drought stress, chilling stress, salt stress, heavy metal stress etc. [9,10]. Many studies have reported an increase in abscisic acid levels under the stress of various heavy metals such as $\mathrm{Cu}, \mathrm{Ni}, \mathrm{Cd}, \mathrm{Hg}$ etc. [11,12]. An increase in the endogenous content of abscisic acid increased tolerance to $\mathrm{Cd}$ in Oryza sativa $\mathrm{L}$. seedlings [13]. BRs regulate a number of physiological processes in plants such as differentiation of tracheary elements, cell division, cell elongation, seed germination, cell membrane polarization, senescence etc. In the recent past more research has been focussed on BRs as they are also involved in increasing plant tolerance to various abiotic and biotic stresses. They provide resistance to plants against heavy metal stress by reducing the uptake of metals by roots; increasing the activity of antioxidants and antioxidant enzymes for detoxification of ROS; regulating the endogenous levels of other plant hormones such as auxins, abscisic acid, polyamines etc. [14]. 
In the present study we investigated the effects of $\mathrm{Cu}(\mathrm{II})$ and exogenous 24-EpiBR, alone and in combination, on various parameters such as shoot weight; root weight; the endogenous levels of abscisic acid and auxins such as indole acetic acid (IAA), indole butyric acid (IBA), phenylacetic acid (PAA); contents of lipids such as phospholipids, total sterols and esterified sterols and the contents of sugars such as glucose and sucrose in the 30-day old $B$. juncea plants.

\section{Materials and methods}

Certified seeds of B. juncea were procured from Punjab Agricultural University, Punjab, India. A field was prepared according to randomized block design and different blocks were given the treatment of different concentrations of $\mathrm{Cu}(\mathrm{II})$ solutions $(0,0.25,0.50$ and $0.75 \mathrm{mM})$. Seeds of $B$. juncea were surface sterilized and pre-soaked in different concentrations of $24-\operatorname{EpiBR}(0,0.01,1$ and $100 \mathrm{nM})$. The seeds were then sown in the field and the plants were harvested after 30 days of the sowing.

\subsection{Morphological parameters}

Shoot and root weights of the harvested plants were measured.

\subsection{Estimation of lipid peroxidation (MDA content)}

Lipid peroxidation was determined following the method of Heath and Packer [15]. Homogenised $1 \mathrm{~g}$ of the plant sample in $3 \mathrm{ml}$ of $0.1 \%$ trichloroacetic acid. Then centrifuged the homogenised samples for $5 \mathrm{~min}$ at 10,000 r.p.m. The resulting supernatant was removed and $3 \mathrm{ml}$ of thiobarbituric acid was added into it. The resulting solution was heated in a water bath at $95^{\circ} \mathrm{C}$. After $30 \mathrm{~min}$ it was removed from the water bath and was cooled immediately for the reaction to stop. Its absorbance was taken at $532 \mathrm{~nm}$ and $600 \mathrm{~nm}$.

Lipid peroxidation was calculated in terms of MDA content $[\mu \mathrm{mol} \mathrm{g} /$ fresh weight $(\mathrm{FW})]$ formed. It was calculated by the following formula:

$$
\mathrm{MDA}=\frac{\text { Absorbance } \times \text { Total volume }(\mathrm{ml}) \times 1000}{\text { Extinction coefficient } \times \text { sample volume }(\mathrm{ml}) \times \text { weight of plant material }}
$$

Here, Absorbance $=$ absorbance at $532 \mathrm{~nm}-$ absorbance at $600 \mathrm{~nm}$ and extinction coefficient $=155 \mathrm{mM}^{-1} \mathrm{~cm}^{-1}$.

\subsection{Estimation of lipids}

Extraction: For the extraction of lipids, method of Kates [16] was used. Leaves of B. juncea were homogenised with methanol-chloroform (2:1). After the filtration of the homogenate, the filter residue was washed using $30 \mathrm{ml}$ of methanol-chloroform $(2: 1)$. All the filtrates were combined and were put in a separatory funnel. $58 \mathrm{ml}$ of water and $50 \mathrm{ml}$ of chloroform were added into the mixture. Chloroform layer was taken out and dried. The residual lipids were then dissolved in chloroform.

\subsubsection{Phospholipids}

Phospholipids were estimated using the method of Ames and Dubin [17]. Chloroform was evaporated from the test extract taken in a test tube. Then, added $10 \%$ of magnesium nitrate into it. The solution was heated first on low flame and after that on strong flame. $0.5 \mathrm{~N} \mathrm{HCl}$ was added to it, followed by heating in boiling water bath. After that tubes were cooled. A reagent was prepared by mixing ammonium molybdate $(0.42 \mathrm{w} / \mathrm{v}$ in $\left.1 \mathrm{~N} \mathrm{H}_{2} \mathrm{SO}_{4}\right)$ and ascorbic acid $(10 \% \mathrm{w} / \mathrm{v})$. The $4.2 \mathrm{ml}$ of this reagent was added to the sample solution obtained above and was incubated at $45^{\circ} \mathrm{C}$. Absorbance was noted at $820 \mathrm{~nm}$ against a blank. A standard curve was prepared using potassium dihydrogen orthophosphate and was used to estimate the phosphorous amount in the samples.

\subsubsection{Total sterols}

We used the method of Sperry and Webb [18]. Test extract was taken in a test tube. $1 \mathrm{ml}$ of acetic anhydride, $5 \mathrm{ml}$ of chloroform and $0.1 \mathrm{ml}$ of conc. $\mathrm{H}_{2} \mathrm{SO}_{4}$ were added into the test tube. Absorbance of the resulting solution was noted down at $625 \mathrm{~nm}$ against blank. A standard curve prepared using ergosterol was used to calculate the content of total sterols.

\subsubsection{Esterified sterols}

To the lipid sample taken in a test tube, $1 \%$ solution of digitonin was added. The mixture was kept till evaporation. It was followed by the addition of $3 \mathrm{ml}$ of petroleum ether. Tubes were heated in a water bath until the evaporation of half of the solvent. The method used for the estimation of total sterols was then followed for the estimation of esterified sterols. 
24-epibrassinolide mediated regulation of endogenous contents of auxins, abscisic acid, lipids ...

\subsection{Estimation of sugars}

Extraction: Sugars were extracted using the method of Singh and Luthra [19]. Ethanol was used for the extraction of lipids from the leaves of $B$. juncea plants in a boiling water bath. Extracts were dried to aqueous syrup using rotary vacuum evaporator. Final volume was raised to $100 \mathrm{ml}$ with distilled water.

\subsubsection{Glucose}

Method of Gascon and Lampen [20] was used for the estimation of glucose. For it three reagents were prepared. Reagent 'A': $50 \mathrm{mg}$ of glucose oxidase was added to $0.1 \mathrm{M}$ potassium phosphate buffer of $\mathrm{pH}$ 7.0. To this solution, $2.5 \mathrm{mg}$ of peroxidise was added. Reagent ' $\mathrm{B}$ ': o-dianisidine $(30 \mathrm{mg})$ was added to methanol. Reagent ' $C$ ': $45 \%$ of glycerol, $6 \mathrm{ml}$ of reagent $\mathrm{A}$ and $3 \mathrm{ml}$ of reagent ' $\mathrm{B}$ ' were mixed together for the preparation of reagent ' $\mathrm{C}$ '. Procedure: To the test extract taken in a test tube, $1 \mathrm{ml}$ of reagent ' $\mathrm{C}$ ' was added. It was followed by the addition of $2 \mathrm{ml}$ of $2 \mathrm{~N} \mathrm{HCl}$. Took absorbance at $540 \mathrm{~nm}$. A standard curve was prepared using glucose and was used to calculate the amount of glucose in the test sample.

\subsubsection{Sucrose}

Sucrose estimation was done using the method of Roe [21], with some changes. To the test extract, we added $0.5 \mathrm{ml}$ of $6 \% \mathrm{KOH}$. The mixture was heated in a boiling water bath. Cooled the mixture, followed by the addition of $1 \mathrm{ml}$ of resorcinol $(0.1 \%)$ and $3 \mathrm{ml}$ of $\mathrm{HCl}(30 \%)$. The resulting solution was incubated for $10 \mathrm{~min}$ at $80^{\circ} \mathrm{C}$. Absorbance was taken at $490 \mathrm{~nm}$. A standard curve prepared using sucrose was used to calculate the amount of sucrose present in the sample.

\subsection{Estimation of endogenous contents of auxins and abscisic acid}

Sample preparation: $0.50 \mathrm{~g}$ of leaves of B. juncea were subjected to homogenisation in $5 \mathrm{ml}$ of $80 \%$ methanol. The homogenate obtained was centrifuged and the resulting supernatant was filtered through 0.22 micron pore size nylon filter membrane. The filtrate was used to measure the endogenous contents of auxins and abscisic acid.LCMS analysis: The conditions employed by Banerjee and Kulkarni [22] were followed for LCMS analysis. $2 \mu \mathrm{L}$ volume of the filtrate obtained above was injected for LCMS analysis. Mobile phase 'A' was constituted of water $(0.5 \%$ formic acid) and mobile phase ' $\mathrm{B}$ ' was constituted of methanol. Column temperature was set at $40^{\circ} \mathrm{C}$. Flow rate was $200 \mu \mathrm{L} / \mathrm{min} .16 \mathrm{~min}$ run time was set in the positive mode and 6 min run time was set in the negative mode.

\subsection{Statistical analysis}

The data obtained was analysed statistically using self coding software and was presented as mean \pm standard deviation. Two way analysis of variance (ANOVA) was performed. Tukey's multiple comparison test was applied to determine honestly significant difference (HSD). The data was considered significant at $\mathrm{p} \leq 0.05$. The data was also analysed using multiple regression with interaction and $\%$ variability explained was calculated.

\section{Results \\ 3.1 Effect of 24-EpiBR on the plant growth under $\mathrm{Cu}(\mathrm{II})$ stress 3.1.1 Shoot weight}

Shoot weight of the plants decreased with increase in the $\mathrm{Cu}(\mathrm{II})$ treatment in the soil. When compared with the control $(0.38 \mathrm{~g})$, maximum reduction $(-71.05 \%)$ in shoot weight $(0.11 \mathrm{~g})$ was caused by $0.75 \mathrm{mM} \mathrm{Cu}$ (II) treatment to soil. Seed pre-soaking treatment with 24-EpiBR improved shoot weight in the plants grown under $\mathrm{Cu}$ (II) stress. Seed pre-soaking treatment with $100 \mathrm{nM}$ 24-EpiBR was most effective in improving the shoot weight in plants grown in soil applied with various $\mathrm{Cu}(\mathrm{II})$ concentrations, in comparison to the other two 24EpiBR concentrations ( 1 and $0.01 \mathrm{nM}$ ). Binary combination of $100 \mathrm{nM}$ 24-EpiBR with $0.75 \mathrm{mM} \mathrm{Cu}$ (II) caused maximum improvement $(0.20 \mathrm{~g}, 81.8 \%)$ in the shoot weight as compared to the respective $\mathrm{Cu}$ (II) $(0.75 \mathrm{mM})$ alone treatment $(0.11 \mathrm{~g})$ (Table 1$)$. $\mathrm{Cu}(\mathrm{II})$ and 24-EpiBR had F-ratios significant at $\mathrm{P}<0.01$, whereas the F-ratios for $\mathrm{Cu}(\mathrm{II})$ and 24-EpiBR was not significant (Table 1). HSD was $0.06 \mathrm{~g}$. Plants grown in the soil treated with various concentrations of $\mathrm{Cu}(\mathrm{II})(0.25,0.50$ and $0.75 \mathrm{mM})$ showed significant decline in the shoot weight as compared to the control. Binary combination of $100 \mathrm{nM} 24-\mathrm{EpiBR}$ and $0.75 \mathrm{mM} \mathrm{Cu}$ (II) resulted in maximum improvement in the shoot weight (Table 1). The data was analysed with multiple regression with interaction. There was no interaction between $\mathrm{Cu}(\mathrm{II})$ and 24 -EpiBR as evident from the $\beta$-regression $(0.01)$ for $\mathrm{Cu}(\mathrm{II}) \mathrm{x} 24-$ EpiBR (Table 1). Cu(II), 24-EpiBR and their interaction explained $91.07 \%$ of variability (Table 1).

\subsubsection{Root weight}

$\mathrm{Cu}(\mathrm{II})$ application to soil decreased the root weight in 30-day old B. juncea plants as compared to control. 24-EpiBR seed pre-soaking improved root weight in plants grown in $\mathrm{Cu}$ (II) amended soils. Plants raised 
24-epibrassinolide mediated regulation of endogenous contents of auxins, abscisic acid, lipids ...

from the seeds given pre-soaking treatment with $100 \mathrm{nM}$ 24-EpiBR and grown in $0.50 \mathrm{mM} \mathrm{Cu}(\mathrm{II})$ applied soil, showed maximum improvement $(0.03 \mathrm{~g}, 200 \%)$ in the root weight in comparison to the respective $\mathrm{Cu}$ (II) $(0.50$ $\mathrm{mM}$ ) alone treatment (Table 2). $\mathrm{Cu}(\mathrm{II})$ and 24-EpiBR had F-ratios significant at $\mathrm{P}<0.01$, whereas the F-ratio for $\mathrm{Cu}(\mathrm{II}) \mathrm{x} 24-\mathrm{EpiBR}$ was not significant (Table 2). HSD was $0.01 \mathrm{~g}$. As compared to the control, plants grown in soil treated with $\mathrm{Cu}(\mathrm{II})$ showed significant decrease in the root weight. Maximum improvement was caused by the binary combination of $100 \mathrm{nM} 24-\mathrm{EpiBR}$ and $0.50 \mathrm{mM} \mathrm{Cu}$ (II) in comparison to the respective $\mathrm{Cu}$ (II) $(0.50$ $\mathrm{mM}$ ) alone treatment (Table 2). Multiple regression with interaction was applied on the data. The value of $\beta$ regression (-0.21) for $\mathrm{Cu}(\mathrm{II}) \times$ 24-EpiBR showed negative interaction between $\mathrm{Cu}(\mathrm{II})$ and 24-EpiBR (Table 2). $\mathrm{Cu}(\mathrm{II}), 24-\mathrm{EpiBR}$ and their interaction explained $83.48 \%$ variability (Table 2 ).

\subsection{Effect of 24-EpiBR on the relative abundance of auxins under $\mathrm{Cu}(\mathrm{II})$ stress 3.2.1 IAA}

Content of IAA (relative abundance: 104.50) declined (-64.1\%) in the leaves of plants when compared with the control (relative abundance: 291.30). IAA content (relative abundance: 188.30) improved (80.2\%) with the seed pre-soaking treatment with $100 \mathrm{nM} 24-\mathrm{EpiBR}$ in the leaves of plants under the stress of $0.50 \mathrm{mM}$ $\mathrm{Cu}$ (II) (Table 3, Fig. 1). $\mathrm{Cu}(\mathrm{II}), 24-\mathrm{EpiBR}$ and their interaction $(\mathrm{Cu}(\mathrm{II}) \times \mathrm{24}$-EpiBR) had F-ratios significant at $\mathrm{P}<0.01$ (Table 3). HSD for relative abundance was 7.85. As compared to the control, treatment of soil with 0.50 $\mathrm{mM} \mathrm{Cu(II)} \mathrm{significantly} \mathrm{declined} \mathrm{the} \mathrm{IAA} \mathrm{content} \mathrm{in} \mathrm{the} \mathrm{leaves} \mathrm{of} \mathrm{plants.} \mathrm{The} \mathrm{plants} \mathrm{given} \mathrm{seed} \mathrm{pre-soaking}$ treatment with $100 \mathrm{nM} 24-\mathrm{EpiBR}$ and grown in soil applied with $0.50 \mathrm{mM} \mathrm{Cu}(\mathrm{II})$ maximally improved the IAA content in comparison to $0.50 \mathrm{mM} \mathrm{Cu}$ (II) alone treatment (Table 3). The data was subjected to analysis with multiple regression with interaction. $\beta$-regression value $(0.20)$ for $\mathrm{Cu}(\mathrm{II}) \times 24$-EpiBR indicated positive interaction between $\mathrm{Cu}(\mathrm{II})$ and 24-EpiBR (Table 3). 99.90\% variability was explained by $\mathrm{Cu}(\mathrm{II}), 24-\mathrm{EpiBR}$ and their interaction (Table 3).

\subsubsection{IBA}

The leaves of $B$. juncea plants grown in the soil treated with $0.50 \mathrm{mM} \mathrm{Cu}(\mathrm{II})$ showed decline $(-45.3 \%)$ in the IBA content (relative abundance: 910.90) in comparison to the control (relative abundance: 1666.50). Seed pre-soaking with $100 \mathrm{nM}$ 24-EpiBR improved (42.6\%) the content of IBA (relative abundance: 1298.80) in the leaves of plants grown under $0.50 \mathrm{mM} \mathrm{Cu}(\mathrm{II})$ stress (Table 4, Fig. 2). $\mathrm{Cu}(\mathrm{II}), 24-\mathrm{EpiBR}$ and $\mathrm{Cu}$ (II) x 24EPiBR had F-ratios significant at $\mathrm{P}<0.01$ (Table 4). HSD for relative abundance was 19.73 . As compared to control, a significant decline was observed in the IBA content in leaves of plants grown in soil applied with 0.50 $\mathrm{mM} \mathrm{Cu}(\mathrm{II})$. Plants raised from the seeds pre-soaked with $100 \mathrm{nM}$ 24-EpiBR and grown in soil treated with 0.50 $\mathrm{mM} \mathrm{Cu}(\mathrm{II})$ showed maximum improvement in the IBA content as compared to the respective $\mathrm{Cu}(\mathrm{II})(0.50 \mathrm{mM})$ alone treatment (Table 4). The data was also analysed with multiple regression with interaction. $\beta$-regression (0.53) for $\mathrm{Cu}(\mathrm{II}) \mathrm{x} 24-\mathrm{EpiBR}$ indicated positive interaction between $\mathrm{Cu}(\mathrm{II})$ and 24-EpiBR (Table 4). $\mathrm{Cu}(\mathrm{II}), 24-$ EpiBR and their interaction explained $99.94 \%$ variability (Table 4).

\subsubsection{PAA}

PAA content (relative abundance: 1486.40) decreased (-46.2\%) in the leaves of plants grown under the stress of $0.50 \mathrm{mM} \mathrm{Cu}(\mathrm{II})$ when compared with the control (relative abundance: 2761.90$)$. The leaves of plants grown in the soil treated with $0.50 \mathrm{mM} \mathrm{Cu}(\mathrm{II})$ but raised from the seeds given pre-soaking treatment with 100 nM 24-EpiBR, showed an improvement (17.8\%) in the content of PAA (relative abundance: 1751.20) (Table 5, Fig. 3). The F-ratios for $\mathrm{Cu}(\mathrm{II}), 24-\mathrm{EpiBR}$ and $\mathrm{Cu}(\mathrm{II}) \times 24-\mathrm{EpiBR}$ were significant at $\mathrm{P}<0.01$ (Table 5). HSD for relative abundance was 15.09 . In comparison to the control, $0.50 \mathrm{mM} \mathrm{Cu}$ (II) solution given to the soil caused significant decrease in the PAA content in the leaves of plants. Binary combination of $100 \mathrm{nM}$ 24-EpiBR and $0.50 \mathrm{mM} \mathrm{Cu}(\mathrm{II})$ resulted in significant improvement in PAA content in the leaves of plants as compared to the plants treated with $0.50 \mathrm{mM} \mathrm{Cu}$ (II) solution alone (Table 5). The data was analysed with multiple regression with interaction. Since, $\beta$-regression for $\mathrm{Cu}(\mathrm{II}) \mathrm{x} 24$-EpiBR was 0.13 , there was positive interaction between soil $\mathrm{Cu}(\mathrm{II})$ treatment and 24-EpiBR seed pre-soaking treatment (Table 5). $\mathrm{Cu}(\mathrm{II}), 24-\mathrm{EpiBR}$ and their interaction explained $1 \%$ variability (Table 5).

\subsection{Effect of 24-EpiBR on the relative abundance of abscisic acid under $\mathrm{Cu}$ (II) stress}

Abscisic acid (relative abundance: 1901.10) enhanced (443.9\%) in leaves of the plants grown in $\mathrm{Cu}(\mathrm{II})$ treated soil in comparison to the control (relative abundance: 349.50 ). Abscisic acid content (relative abundance: 3041.80) enhanced (60\%) further in the leaves of plants raised from the seeds pre-soaked with 24-EpiBR and grown in $0.50 \mathrm{mM} \mathrm{Cu}$ (II) treated soil as compared to the plants given no 24-EpiBR seed pre-soaking but grown in the soil treated with $0.50 \mathrm{mM} \mathrm{Cu}$ (II) solution (Table 6, Fig. 4). F-ratios for separate treatments of $\mathrm{Cu}$ (II) and 24-EpiBR and also for their interaction (Cu(II) x 24-EpiBR) were significant at $\mathrm{P}<0.01$ (Table 6). HSD for relative abundance was 13.56. The leaves of plants grown in the soil applied with $0.50 \mathrm{mM} \mathrm{Cu}$ (II) solution 
showed significant enhancement in the abscisic acid content in comparison to the control. Plants grown in soil applied with $0.50 \mathrm{mM} \mathrm{Cu}$ (II) which were given seed pre-soaking treatment with $100 \mathrm{nM}$ 24-EpiBR showed significant enhancement in the abscisic acid content in their leaves as compared to the soil $0.50 \mathrm{mM} \mathrm{Cu}$ (II) alone treatment (Table 6). The data was subjected to analysis with multiple regression with interaction. $\mathrm{Cu}(\mathrm{II})$ and 24-EpiBR interacted negatively as evident from the $\beta$-regression value $(-0.16)$ for $\mathrm{Cu}(\mathrm{II}) \times 24$-EpiBR (Table 6). $1 \%$ variability was explained by $\mathrm{Cu}(\mathrm{II}), 24-\mathrm{EpiBR}$ and their interaction (Table 6 ).

\subsection{Effect of 24-EpiBR on lipid peroxidation and lipids content under $\mathrm{Cu}$ (II) stress 3.4.1 Lipid peroxidation}

Plants grown in soil applied with different concentrations of $\mathrm{Cu}(\mathrm{II})$ solutions $(0.25,0.50$ and $0.75 \mathrm{mM})$ showed elevation in MDA content in their leaves as compared to the control $\left(0.98 \mu \mathrm{mol} \mathrm{g}^{-1} \mathrm{FW}\right)$. Maximum enhancement $(40.8 \%)$ in the MDA content $\left(1.38 \mu \mathrm{mol} \mathrm{g}{ }^{-1} \mathrm{FW}\right)$ was observed in the leaves of plants grown in $0.75 \mathrm{mM} \mathrm{Cu}$ (II) treated soil. 24-EpiBR seed pre-soaking declined the MDA content in the leaves of plants grown in $\mathrm{Cu}(\mathrm{II})$ treated soil. Plants raised from the seeds given pre-soaking treatment with $100 \mathrm{nM}$ 24-EpiBR and grown in $0.75 \mathrm{mM} \mathrm{Cu}(\mathrm{II})$ applied soil showed maximum decline in the content of $\mathrm{MDA}\left(1.17 \mu \mathrm{mol} \mathrm{g}^{-1} \mathrm{FW}\right.$, $-15.2 \%)$ in their leaves in comparison to the respective $\mathrm{Cu}(\mathrm{II})(0.75 \mathrm{mM})$ alone treatment $\left(1.38 \mu \mathrm{mol} \mathrm{g} \mathrm{g}^{-1} \mathrm{FW}\right)$ (Table 7). F-ratio values for $\mathrm{Cu}(\mathrm{II})$ and 24-EpiBR had F-ratios significant at $\mathrm{P}<0.01$, whereas F-ratio value for $\mathrm{Cu}$ (II) x 24-EpiBR was not significant (Table 7). HSD was $0.09 \mu \mathrm{mol} \mathrm{g}^{-1} \mathrm{FW}$. $\mathrm{Cu}$ (II) treatments to soil led to significant enhancement in the lipid peroxidation in comparison to the control. Lipid peroxidation declined to the maximum in the binary combination of $100 \mathrm{nM}$ 24-EpiBR and $0.75 \mathrm{mM} \mathrm{Cu}(\mathrm{II})$ when compared with the respective $\mathrm{Cu}(\mathrm{II})(0.75 \mathrm{mM})$ alone treatment (Table 7). Data was analysed with multiple regression with interaction. Since, $\beta$-regression value for $\mathrm{Cu}$ (II) $\times$ 24-EpiBR was -0.22 , there was negative interaction between $\mathrm{Cu}$ (II) and 24-EpiBR (Table 7). $\mathrm{Cu}(\mathrm{II}), 24-\mathrm{EpiBR}$ and their interaction explained $83.50 \%$ of variability (Table 7).

\subsection{Lipids \\ 3.5.1 Phospholipids}

A decline was observed in the content of phospholipids in the leaves of plants grown in soils treated with $\mathrm{Cu}$ (II) as compared to the control $\left(0.10 \mathrm{mg} \mathrm{g}^{-1} \mathrm{FW}\right) .0 .75 \mathrm{mM} \mathrm{Cu}$ (II) soil treatment $\left(0.02 \mathrm{mg} \mathrm{g}^{-1} \mathrm{FW}\right)$ caused the maximum decline (-80\%). 24-EpiBR seed pre-soaking treatment improved the phospholipids content in the leaves of plants grown in soil applied with $\mathrm{Cu}(\mathrm{II})$ solutions. Plants raised from the seeds given presoaking treatment with $100 \mathrm{nM}$ 24-EpiBR and grown in soil applied with $0.75 \mathrm{mM} \mathrm{Cu}(\mathrm{II})$, showed maximum improvement $\left(0.06 \mathrm{mg} \mathrm{g}^{-1} \mathrm{FW}, 200 \%\right)$ in the phospholipids content in their leaves in comparison to the plants without seed pre-soaking treatment of 24-EpiBR but grown in the respective $\mathrm{Cu}(\mathrm{II})(0.75 \mathrm{mM})$ alone treatment $\left(0.02 \mathrm{mg} \mathrm{g}^{-1} \mathrm{FW}\right.$ ) (Table 8). F-ratios for $\mathrm{Cu}$ (II) and 24-EpiBR were significant at $\mathrm{P}<0.01$ but $\mathrm{F}$-ratio for $\mathrm{Cu}(\mathrm{II}) \mathrm{x}$ 24-EpiBR was not significant (Table 8). HSD was $0.02 \mathrm{mg} \mathrm{g}^{-1} \mathrm{FW}$. Content of phospholipids decreased significantly in comparison to the control by treatment of soil with $\mathrm{Cu}(\mathrm{II})$ solutions of different concentrations $(0.25,0.50$ and $0.75 \mathrm{mM})$. Binary combination of $100 \mathrm{nM}$ 24-EpiBR and $0.75 \mathrm{mM} \mathrm{Cu}$ (II) improved the phospholipids content to the maximum when compared with the respective $\mathrm{Cu}(\mathrm{II})(0.75 \mathrm{mM})$ alone treatment (Table 8). Multiple regression with interaction analysis was performed on the data. $\beta$-regression for $\mathrm{Cu}(\mathrm{II}) \times 24-$ EpiBR was 0.17. It showed that $\mathrm{Cu}(\mathrm{II})$ and 24-EpiBR interacted positively (Table 8). $\mathrm{Cu}(\mathrm{II}), 24-\mathrm{EpiBR}$ and their interaction explained $83.56 \%$ of variability (Table 8 ).

\subsubsection{Total sterols}

Application of various concentrations $(0.25,0.50$ and $0.75 \mathrm{mM})$ of $\mathrm{Cu}(\mathrm{II})$ solution in soil caused decline in the content of total sterols in the leaves of plants. Maximum reduction $(-56 \%)$ was observed in the plants grown in soil applied with $0.75 \mathrm{mM} \mathrm{Cu}(\mathrm{II})$ solution $\left(1.85 \mathrm{mg} \mathrm{g}^{-1} \mathrm{FW}\right)$ in comparison to the control $(4.20$ $\left.\mathrm{mg} \mathrm{g}^{-1} \mathrm{FW}\right)$. An improvement was observed in the content of total sterols in leaves of the plants raised from the seeds given 24-EpiBR seed pre-soaking and grown in soil treated with $\mathrm{Cu}(\mathrm{II})$. Binary combination of $100 \mathrm{nM}$ 24-EpiBR and $0.75 \mathrm{mM} \mathrm{Cu}(\mathrm{II})$ caused maximum elevation $\left(4.05 \mathrm{mg} \mathrm{g}^{-1} \mathrm{FW}, 118.9 \%\right)$ in the content of total sterols in the plant leaves as compared to the plants given $0.75 \mathrm{mM} \mathrm{Cu}$ (II) alone treatment $\left(1.85 \mathrm{mg} \mathrm{g}^{-1} \mathrm{FW}\right)$ (Table 9). $\mathrm{Cu}(\mathrm{II}), 24-\mathrm{EpiBR}$ and $\mathrm{Cu}(\mathrm{II}) \times 24-\mathrm{EpiBR}$ had F-ratio values significant at $\mathrm{P}<0.01$ (Table 9). HSD was $0.27 \mathrm{mg} \mathrm{g}^{-1} \mathrm{FW}$. Various concentrations of $\mathrm{Cu}$ (II) solutions applied in soil resulted in significant decline in the content of total sterols in comparison to the control. The content of total sterols improved maximally by the binary combination of $100 \mathrm{nM}$ 24-EpiBR and $0.75 \mathrm{mM} \mathrm{Cu}$ (II) when compared with the respective $(0.75 \mathrm{mM})$ $\mathrm{Cu}(\mathrm{II})$ alone treatment (Table 9). Multiple regression with interaction analysis was performed on the data. $\mathrm{Cu}(\mathrm{II})$ and 24-EpiBR interacted positively to increase the total sterols as evident from the $\beta$-regression (0.14) for $\mathrm{Cu}(\mathrm{II})$ x 24-EpiBR (Table 9). Cu(II), 24-EpiBR and their interaction explained $60.79 \%$ of variability (Table 9). 
24-epibrassinolide mediated regulation of endogenous contents of auxins, abscisic acid, lipids ...

\subsubsection{Esterified sterols}

$\mathrm{Cu}$ (II) stress declined the esterified sterols content in the leaves of $B$. juncea plants. $0.75 \mathrm{mM} \mathrm{Cu}(\mathrm{II})$ soil treatment caused maximum decrease $(-54.7 \%)$ in the esterified sterols $\left(0.58 \mathrm{mg} \mathrm{g}^{-1} \mathrm{FW}\right)$ in comparison to the control $\left(1.28 \mathrm{mg} \mathrm{g}^{-1} \mathrm{FW}\right)$. As compared to the individual $\mathrm{Cu}(\mathrm{II})$ alone treatments, the leaves of plants raised from the seeds pre-soaked in $1 \mathrm{nM}$ 24-EpiBR and grown in $0.50 \mathrm{mM} \mathrm{Cu}(\mathrm{II})$ applied soil, showed maximum increase $\left(1.12 \mathrm{mg} \mathrm{g}^{-1} \mathrm{FW}, 51.4 \%\right)$ in the content of esterified sterols (Table 10). When $\mathrm{Cu}(\mathrm{II})$ and 24-EpiBR were applied alone, their F-ratios were significant at $\mathrm{P}<0.01$. Their interaction (Cu(II) x 24-EpiBR) had F-ratio significant at $\mathrm{P}<0.05$ (Table 10). HSD was $0.08 \mathrm{mg} \mathrm{g}^{-1} \mathrm{FW}$. In comparison to the control, leaves of the plants grown in soil amended with different concentrations of $\mathrm{Cu}(\mathrm{II})$ solutions $(0.25,0.50$ and $0.75 \mathrm{mM})$, showed significant decrease in the content of esterified sterols. Esterified sterols content improved maximally by the binary combination of $1 \mathrm{nM} 24-\mathrm{EpiBR}$ and $0.50 \mathrm{mM} \mathrm{Cu}$ (II) as compared to the respective $\mathrm{Cu}$ (II) $(0.50 \mathrm{mM})$ alone treatment (Table 10). The data was analysed with multiple regression with interaction. $\beta$-regression for $\mathrm{Cu}(\mathrm{II}) \times$ 24-EpiBR (0.11) revealed positive interaction between $\mathrm{Cu}(\mathrm{II})$ and 24-EpiBR (Table 10). $\mathrm{Cu}(\mathrm{II}), 24-$ EpiBR and their interaction explained $85.78 \%$ variability (Table 10 ).

\subsection{Effect of 24-EpiBR on sugars under $\mathrm{Cu}(\mathrm{II})$ stress 3.6.1 Glucose}

Plants grown in $\mathrm{Cu}(\mathrm{II})$ amended soils showed decrease in the glucose content in their leaves. In comparison to the control $\left(0.81 \mathrm{mg} \mathrm{g}^{-1} \mathrm{FW}\right)$, leaves of the plants grown in the soil treated with $0.75 \mathrm{mM} \mathrm{Cu}(\mathrm{II})$, showed maximum decrease (-40.7\%) in the content of glucose $\left(0.48 \mathrm{mg} \mathrm{g}^{-1} \mathrm{FW}\right)$. Plants raised from the seeds given pre-soaking treatment with 24-EpiBR and then grown in the soil amended with solutions of various $\mathrm{Cu}(\mathrm{II})$ concentrations, showed improvement in the glucose content in their leaves in comparison to the respective $\mathrm{Cu}$ (II) alone treatments. In such comparison, maximum improvement $\left(0.84 \mathrm{mg} \mathrm{g}^{-1} \mathrm{FW} ; 52.7 \%\right)$ was observed in the binary combination of $100 \mathrm{nM} 24-\mathrm{EpiBR}$ and $0.50 \mathrm{mM} \mathrm{Cu}$ (II) when compared with the $\mathrm{Cu}$ (II) $(0.50 \mathrm{mM})$ alone treatment $\left(0.55 \mathrm{mg} \mathrm{g}^{-1} \mathrm{FW}\right)$ (Table 11). F-ratio values for $\mathrm{Cu}(\mathrm{II})$ and 24-EpiBR were significant at $\mathrm{P}<0.01$ whereas F-ratio value for $\mathrm{Cu}(\mathrm{II}) \times 24-\mathrm{EpiBR}$ was not significant (Table 11). HSD was $0.05 \mathrm{mg} \mathrm{g}^{-1} \mathrm{FW}$. The leaves of plants grown in the soil applied with $\mathrm{Cu}(\mathrm{II})$ showed significant decline in glucose amount as compared to the control. Maximum improvement was noted in the binary combination of $100 \mathrm{nM} 24-\mathrm{EpiBR}$ and $0.50 \mathrm{mM}$ $\mathrm{Cu}(\mathrm{II})$ in comparison to the respective $\mathrm{Cu}(\mathrm{II})(0.50 \mathrm{mM})$ alone treatment (Table 11). Multiple regression with interaction analysis was performed on the data. Since, the $\beta$-regression value for $\mathrm{Cu}(\mathrm{II}) \times 24$-EpiBR was 0.15 , there was positive interaction between $\mathrm{Cu}(\mathrm{II})$ and 24-EpiBR (Table 11). $\mathrm{Cu}(\mathrm{II}), 24-\mathrm{EpiBR}$ and their interaction explained $82.92 \%$ of variability (Table 11 ).

\subsubsection{Fructose}

An increase was reported in the fructose in the leaves of plants grown in the soil applied with $\mathrm{Cu}(\mathrm{II})$ solution in comparison to the control $\left(0.37 \mathrm{mg} \mathrm{g}^{-1} \mathrm{FW}\right)$, with maximum increase $(94.6 \%)$ noted in the leaves of plants grown in $0.75 \mathrm{mM} \mathrm{Cu}(\mathrm{II})$ treated soil $\left(0.72 \mathrm{mg} \mathrm{g}^{-1} \mathrm{FW}\right)$. A further elevation was observed under $\mathrm{Cu}(\mathrm{II})$ stress in the leaves of plants raised from seeds given pre-soaking treatment of 24-EpiBR. The leaves of plants raised from the seeds given pre-soaking treatment with $1 \mathrm{nM}$ 24-EpiBR and grown in the soil amended with $0.50 \mathrm{mM} \mathrm{Cu}(\mathrm{II})$, showed maximum enhancement $\left(0.80 \mathrm{mg} \mathrm{g}^{-1} \mathrm{FW}, 29 \%\right)$ in the fructose content as compared to the respective $\mathrm{Cu}$ (II) $(0.50 \mathrm{mM})$ alone treatment $\left(0.62 \mathrm{mg} \mathrm{g}^{-1} \mathrm{FW}\right)$ (Table 12). $\mathrm{Cu}$ (II) and 24-EpiBR had F-ratio values significant at $\mathrm{P}<0.01$. F-ratio value for the interaction between $\mathrm{Cu}(\mathrm{II})$ and 24 -EpiBR was not significant (Table 12). HSD was $0.05 \mathrm{mg} \mathrm{g}^{-1} \mathrm{FW}$. When compared with the control, fructose content decreased significantly in the leaves of plants grown in the soils amended with various concentrations $(0.25,0.50$ and $0.75 \mathrm{mM})$ of $\mathrm{Cu}$ (II) solutions. When comparison was done with the $\mathrm{Cu}(\mathrm{II})$ alone treatments, the content of fructose showed maximum enhancement in the leaves of plants raised from the seeds given pre-soaking treatment with $1 \mathrm{nM} 24$ EpiBR and grown in the soil applied with $0.50 \mathrm{mM} \mathrm{Cu}(\mathrm{II})$ (Table 12). The data was subjected to analysis with multiple regression with interaction. There was very little interaction between $\mathrm{Cu}(\mathrm{II})$ and 24-EpiBR as evident from the $\beta$-regression value (0.02) for $\mathrm{Cu}(\mathrm{II}) \mathrm{x}$ 24-EpiBR (Table 12). $\mathrm{Cu}(\mathrm{II}), 24-\mathrm{EpiBR}$ and their interaction explained $86.16 \%$ of variability (Table 12 ).

\section{Discussion}

As the concentration of $\mathrm{Cu}$ (II) application in soil increased, the more reduction was observed in the shoot weight. The reduction in the shoot and root weights of plants under $\mathrm{Cu}(\mathrm{II})$ application shows that the $\mathrm{Cu}$ (II) when present in excess adversely affects the plant growth. The reduction in the plant growth under $\mathrm{Cu}$ (II) stress might be due to the reduction in cell wall elasticity due to the over accumulation of $\mathrm{Cu}$ in cell walls. $\mathrm{Cu}$ declined the shoot and root FW in four genotypes of Solanum melongena L. [23]. Negative effects of $\mathrm{Cu}$ stress on shoot and root weight of Hordeum vulgare and Sinapis alba were observed by Gvozdenac et al. [24], and on shoot weight of Phaseolus vulgaris were observed by Ashagre et al. [25]. We observed an improvement in the 
shoot and root weights when $\mathrm{Cu}(\mathrm{II})$ treatment was supplemented with 24-EpiBR. The improvement might be due to the enhancement in the content of auxins with 24-EpiBR application as compared to the auxins content in $\mathrm{Cu}(\mathrm{II})$ alone treatment. Similar ameliorative effects of 24-EpiBR under $\mathrm{Cu}$ stress were observed by Choudhary et al. [26] in the seedlings of Raphanus sativus.

$\mathrm{Cu}$ adversely affects the plant growth which subsequently reduces the plant biomass in terms of reduced shoot and root weights. To test our hypothesis that whether this reduction in the shoot and root weights was due to the effect of $\mathrm{Cu}(\mathrm{II})$ on the auxin content of $B$. juncea plants, we determined their relative abundance through LCMS. A correlation in the reduction in the auxins content and the resulting decrease in the shoot and root biomass under $\mathrm{Cu}(\mathrm{II})$ stress has been found in our investigation.

Decline in the content of auxin in Populus canescens plants under $\mathrm{Cd}$ treatment was observed by Elobeid et al. [27]. The effect of $\mathrm{Cu}$ and $\mathrm{Cd}$ on auxin degradation was evaluated by Chaoui and Ferjani [28] in pea leaves by determining the activity of IAA oxidase, the enzyme responsible for the auxin breakdown. They observed that the activity of IAA oxidase enhanced with increase in the concentrations of $\mathrm{Cu}$ and $\mathrm{Cd}$ which caused the oxidation of auxin. $\mathrm{Cu}$ at high concentrations affects the auxin content in the cotyledons and apices of primary roots of Arabidopsis [29]. Cu led decline in the auxins levels was reported by Kolbert et al. [30] in Arabidopsis thaliana L. plants, which was responsible for the decrease in the growth of plants. IAA application enhanced the total FW of Musa sp. as compared to the untreated plants. IBA enhanced the shoot and root FW of the seedlings grown under the stress of alpha endosulfan and lindane contaminated soils [31]. In the present study FW of shoots and roots and auxin content increased by the seed pre-soaking treatment of 24-EpiBR. It has been proposed by Nassar [32] that BRs might not act directly on plant growth but might be the enhancer of plant growth by interacting with endogenous or exogenous growth regulators such as auxins. Interdependent and synergistic interaction of BRs and auxins to increase the plant growth was shown by Nemhauser et al. [33] in Arabidopsis plants. They reported that there was strong interaction between auxin and BRs controlled gene regulation and tissue elongation. Mandava [34] proposed that BRs influence plant growth by elevating the auxin action.

Abscisic acid participates in the plant responses to various environmental stresses. Monni et al. [12] reported increase in abscisic acid content in plants exposed to heavy metals such as $\mathrm{Ni}$ and $\mathrm{Cu}$. Abscisic acid helps the plants in adapting to environmental stress. For e.g. under the conditions of water deficit the endogenous amount of abscisic acid enhances which prevents the water loss through transpiration by decreasing the size of stomatal aperture. Increase in the content of abscisic acid under $\mathrm{Zn}$ and $\mathrm{Cu}$ stresses increased the metalothionenins content in Prosopis juliflora, thereby helped in the managing the heavy metal stress in the plants [35]. In the present study the seed pre-soaking treatment of 24-EpiBR increased the relative abundance of abscisic acid in B. juncea plants as compared to the control. The supplementation of $\mathrm{Cu}$ (II) treatment with 24EpiBR treatment further increased the content of abscisic acid when compared with the control. Brassinolide induced increase in the levels of abscisic acid has been reported under various abiotic stress conditions. 24EpiBR role in enhancing the chilling tolerance of Chorispora bungeana plants by triggering the production of abscisic acid has been reported by Liu et al. [9]. Exogenously applied brassinolide enhanced the content of abscisic acid in Chlorella vulgaris under heat stress, which increased the thermo-tolerance of the plants [36]. Plant hormones provide stress tolerance not through linear pathways, but through complex interactions with other molecules [37]. There occurs crosstalk between BRs and abscisic acid which is helpful in stress alleviation. Our results are supported by the results of Choudhary et al. [26]. They observed an enhancement in the endogenous content of abscisic acid in Raphanus sativus under $\mathrm{Cu}$ stress with the application of EpiBR.

Heavy metals cause cellular destruction in plants by inducing the oxidative stress due to increased ROS production [38]. ROS damage biomembranes and convert unsaturated fatty acids into hydrocarbon fragments for e.g. MDA [39]. In the present investigation, the increase in the MDA content with increase in the concentrations of $\mathrm{Cu}$ (II) treatments showed increase in the oxidative damage because of increasing metal toxicity. Metals increase lipoxygenase activity which subsequently leads to lipid peroxidation [40]. It was observed in the present study that the MDA content reduced with the supplementation of $\mathrm{Cu}(\mathrm{II})$ treatment with 24-EpiBR. BRs increase the scavenging of ROS by enhancing the amount of various antioxidants and antioxidant enzymes [41]. Reduction in ROS reduces lipid peroxidation and the subsequent damaging effects on the biomembranes organisation. Reduction in the MDA content and so the lipid peroxidation with the coapplication of 24-EpiBR with $\mathrm{NaCl}$ was reported in Oryza sativa L. [42] and also with its co-appication with $\mathrm{Cu}$ in Raphanus sativus seedlings [26].

Lipid peroxidation and then the destruction of the cellular membranes is one of the main effects of heavy metal toxicity. In the present study, lipids such as phospholipids, total sterols and esterified sterols decreased under the $\mathrm{Cu}(\mathrm{II})$ stress. Decrease in phospholipids influences their interactions with membrane intrinsic proteins and negatively affects the membrane integrity. Decline in the phospholipids was observed by Al-Hakimi and Hamada [43] in seedlings of Triticum aestivum under $\mathrm{Cu}$ stress. The results of sterols content were consistent with the results of Hernandez and Cooke [44] who observed a decline in the content of total 
sterols in Pisum sativum under the Cd stress in comparison to the control. Total sterols and phospholipids content reduced in Zygophyllum album and Zygophyllum coccineum grown in the polluted soil as compared to the same plants grown in the unpolluted soil [45]. The decrease in the lipids could be linked with the increased lipid peroxidation under the metal stress. Both the free and esterified sterols decreased under water deficit conditions in the seedlings of Brassica napus L. [46]. It was observed in the present study that the supplementation of $\mathrm{Cu}$ (II) treatment with 24-EpiBR improved the contents all of the lipids. It might be due to the decrease in the lipid peroxidation by 24-EpiBR application.

In the present investigation, the contents of glucose and sucrose decreased in plants grown in soil given $\mathrm{Cu}$ (II) treatments. Azmat and Riaz [47] showed decrease in glucose and sucrose under $\mathrm{Cu}$ stress by their experiments on Vigna radiata. They proposed that this might be due to the damage to the chlorophyll structure due to increased content of $\mathrm{Cu}$, which affected the light absorption by the chlorophyll molecule. Decrease in the sucrose content has been observed under various abiotic stress conditions. Decrease in the content of nonreducing sugars was observed by Verma and Dubey [48] in the rice seedlings with the increase of $\mathrm{Cd}\left(\mathrm{NO}_{3}\right)_{2}$ amount. They proposed that this was due to increase in the activity of sucrose degrading enzymes like sucrose synthase and acid invertase and the decreased activity of sucrose phosphate synthase under Cd stress. Nonreducing sugars declined in two rice cultivars, Ambemohar and Indrayani, due to salt stress [49]. In the present investigation it was observed that in the binary combination of 24-EpiBR and $\mathrm{Cu}(\mathrm{II})$, the sucrose content increased in comparison to the $\mathrm{Cu}(\mathrm{II})$ alone treatments. It was shown by $\mathrm{Yu}$ et al. [50] that the spray of 24EpiBR on cucumber seedlings enhanced the content of sucrose after $6 \mathrm{~h}$ of the treatment. It occurred because of increased activity of sucrose phosphate synthase due to 24-EpiBR application.

\section{Figures and tables}

Table 1. Effect of seed pre-soaking with 24-EpiBR on shoot weight (g) in 30-day old plants of B. juncea grown in soil amended with $\mathrm{Cu}(\mathrm{II})$ solution before sowing.

\begin{tabular}{|c|c|c|c|c|}
\hline Treatments & Control & $0.25 \mathrm{mM} \mathrm{Cu}(\mathrm{II})$ & $0.50 \mathrm{mM} \mathrm{Cu}(\mathrm{II})$ & $0.75 \mathrm{mM} \mathrm{Cu}(\mathrm{II})$ \\
\hline Control & $0.38 \pm 0.046$ & $0.26 \pm 0.046$ & $0.18 \pm 0.044$ & $0.11 \pm 0.026$ \\
\hline 0.01 nM 24-EpiBR & $0.43 \pm 0.026$ & $0.31 \pm 0.070$ & $0.25 \pm 0.026$ & $0.16 \pm 0.046$ \\
\hline 1 nM 24-EpiBR & $0.46 \pm 0.020$ & $0.34 \pm 0.061$ & $0.27 \pm 0.026$ & $0.18 \pm 0.046$ \\
\hline $100 \mathrm{nM}$ 24-EpiBR & $0.48 \pm 0.056$ & $0.35 \pm 0.036$ & $0.31 \pm 0.036$ & $0.20 \pm 0.017$ \\
\hline \multicolumn{5}{|c|}{ Two way ANOVA } \\
\hline \multicolumn{3}{|c|}{ F-ratio $(3,32)(\mathrm{Cu})=91.17 * *$} & \multicolumn{2}{|c|}{ F-ratio $(3,32)(24-E p i B R)=13.28 * *$} \\
\hline \multicolumn{3}{|c|}{ F-ratio $(9,32)(\mathrm{Cu} \times 24$-EpiBR $)=0.12$} & \multicolumn{2}{|l|}{$\mathrm{HSD}=0.06$} \\
\hline \multicolumn{5}{|c|}{ Multiple regression with interaction } \\
\hline \multicolumn{5}{|c|}{$\mathrm{Y}=0.41-0.36(\mathrm{Cu}, \mathrm{mM})+0.001(24-\mathrm{EpiBR}, \mathrm{nM})+4 \mathrm{E}-05(\mathrm{Cu} \times 24-\mathrm{EpiBR})$} \\
\hline \multicolumn{3}{|l|}{$\beta$-regression $(\mathrm{Cu})=-0.93$} & \multicolumn{2}{|c|}{$\beta$-regression $(24-E p i B R)=0.23$} \\
\hline \multicolumn{3}{|c|}{$\beta$-regression $(\mathrm{Cu} \times 24-\mathrm{EpiBR})=0.01$} & \multicolumn{2}{|c|}{$\begin{array}{l}\text { Multiple correlation; } \% \text { variability explained }= \\
0.9543 * * ; 91.07\end{array}$} \\
\hline
\end{tabular}

Table 2. Effect of seed pre-soaking with 24-EpiBR on root weight (g) in 30-day old plants of B. juncea grown in soil amended with $\mathrm{Cu}(\mathrm{II})$ solution before sowing.

\begin{tabular}{|c|c|c|c|c|}
\hline Treatments & Control & $0.25 \mathrm{mM} \mathrm{Cu}(\mathrm{II})$ & $0.50 \mathrm{mM} \mathrm{Cu}(\mathrm{II})$ & $0.75 \mathrm{mM} \mathrm{Cu}(\mathrm{II})$ \\
\hline Control & $0.04 \pm 0.010$ & $0.02 \pm 0.010$ & $0.01 \pm 0.006$ & $0.01 \pm 0.006$ \\
\hline 0.01 nM 24-EpiBR & $0.05 \pm 0.017$ & $0.03 \pm 0.010$ & $0.02 \pm 0.012$ & $0.01 \pm 0.006$ \\
\hline 1 nM 24-EpiBR & $0.06 \pm 0.017$ & $0.03 \pm 0.010$ & $0.02 \pm 0.012$ & $0.02 \pm 0.010$ \\
\hline 100 nM 24-EpiBR & $0.06 \pm 0.010$ & $0.04 \pm 0.017$ & $0.03 \pm 0.010$ & $0.01 \pm 0.006$ \\
\hline \multicolumn{5}{|c|}{ Two way ANOVA } \\
\hline \multicolumn{3}{|c|}{ F-ratio $(3,32)(\mathrm{Cu})=26.07 * *$} & \multicolumn{2}{|c|}{ F-ratio $(3,32)(24$-EpiBR $)=3.84 *$} \\
\hline \multicolumn{3}{|c|}{ F-ratio $(9,32)(\mathrm{Cu} \times 24-$ EpiBR $)=0.51$} & \multicolumn{2}{|l|}{$\mathrm{HSD}=0.01$} \\
\hline \multicolumn{5}{|c|}{ Multiple regression with interaction } \\
\hline \multicolumn{5}{|c|}{$\mathrm{Y}=0.04-0.05(\mathrm{Cu}, \mathrm{mM})+0.0001(24-\mathrm{EpiBR}, \mathrm{nM})-2 \mathrm{E}-04(\mathrm{Cu} \times 24-\mathrm{EpiBR})$} \\
\hline \multicolumn{3}{|l|}{$\beta$-regression $(\mathrm{Cu})=-0.81$} & \multicolumn{2}{|c|}{$\beta$-regression $(24-$ EpiBR $)=0.38$} \\
\hline \multicolumn{3}{|c|}{$\beta$-regression $(\mathrm{Cu} \times 24-E p i B R)=-0.21$} & \multicolumn{2}{|c|}{$\begin{array}{l}\text { Multiple correlation; } \% \text { variability explained } \\
=0.9137^{* * * ; 83.48}\end{array}$} \\
\hline
\end{tabular}

Table 3. Effect of seed pre-soaking with 24-EpiBR on IAA (relative abundance) in the leaves of 30-day old plants of $B$. juncea grown in soil amended with $\mathrm{Cu}(\mathrm{II})$ solution before sowing.

\begin{tabular}{|c|r|r|}
\hline Treatments & Control & 0.50 mM Cu(II) \\
\hline Control & $291.30 \pm 4.55$ & $104.50 \pm 3.52$ \\
\hline 100 nM 24-EpiBR & $334.60 \pm 2.42$ & $188.30 \pm 3.01$ \\
\hline \multicolumn{3}{|c|}{ Two way ANOVA } \\
\hline F-ratio $(1,11)(\mathrm{Cu})=6930.39^{* *}$ & F-ratio $(1,11)(24-\mathrm{EpiBR})=1009.02^{* *}$ \\
\hline F-ratio $(1,11)(\mathrm{Cu} \times 24-\mathrm{EpiBR})=102.45^{* *}$ & HSD = 7.85 \\
\hline \multicolumn{2}{|c|}{ Multiple regression with interaction } \\
\hline
\end{tabular}


Table 8. Effect of seed pre-soaking with 24-EpiBR on phospholipids ( $\mathrm{mg} \mathrm{g}^{-1} \mathrm{FW}$ ) in the leaves of 30-day old plants of $B$. juncea grown in soil amended with $\mathrm{Cu}(\mathrm{II})$ solution before sowing.

\begin{tabular}{|c|c|c|c|c|}
\hline Treatments & Control & $0.25 \mathrm{mM} \mathrm{Cu}(\mathrm{II})$ & $0.50 \mathrm{mM} \mathrm{Cu}(\mathrm{II})$ & $0.75 \mathrm{mM} \mathrm{Cu}(\mathrm{II})$ \\
\hline Control & $0.1 \pm 0.010$ & $0.05 \pm 0.010$ & $0.04 \pm 0.010$ & $0.02 \pm 0.010$ \\
\hline 0.01 nM 24-EpiBR & $0.11 \pm 0.020$ & $0.07 \pm 0.017$ & $0.05 \pm 0.010$ & $0.03 \pm 0.010$ \\
\hline 1 nM 24-EpiBR & $0.12 \pm 0.026$ & $0.09 \pm 0.010$ & $0.06 \pm 0.026$ & $0.05 \pm 0.010$ \\
\hline 100 nM 24-EpiBR & $0.12 \pm 0.017$ & $0.08 \pm 0.010$ & $0.07 \pm 0.010$ & $0.06 \pm 0.017$ \\
\hline \multicolumn{5}{|c|}{ Two way ANOVA } \\
\hline \multicolumn{3}{|c|}{ F-ratio $(3,32)(\mathrm{Cu})=50.81 * *$} & \multicolumn{2}{|c|}{ F-ratio $(3,32)(24-$ EpiBR $)=10.16^{* *}$} \\
\hline \multicolumn{3}{|c|}{ F-ratio $(9,32)(\mathrm{Cu} \times 24-$ EpiBR $)=0.43$} & \multicolumn{2}{|l|}{$\mathrm{HSD}=0.02$} \\
\hline \multicolumn{5}{|c|}{ Multiple regression with interaction } \\
\hline \multicolumn{5}{|c|}{$\mathrm{Y}=0.10-0.10(\mathrm{Cu}, \mathrm{mM})+8 \mathrm{E}-05(24-\mathrm{EpiBR}, \mathrm{nM})+0.0002(\mathrm{Cu} \times 24-\mathrm{EpiBR})$} \\
\hline \multicolumn{3}{|c|}{$\beta$-regression $(\mathrm{Cu})=-0.93$} & \multicolumn{2}{|c|}{$\beta$-regression $(24-E p i B R)=0.11$} \\
\hline \multicolumn{3}{|c|}{$\beta$-regression $(\mathrm{Cu} \times 24-\mathrm{EpiBR})=0.17$} & \multicolumn{2}{|c|}{$\begin{array}{l}\text { Multiple correlation; } \% \text { variability } \\
\text { explained }=0.9141^{* * *} ; 83.56\end{array}$} \\
\hline
\end{tabular}

Table 9. Effect of seed pre-soaking with 24-EpiBR on total sterols $\left(\mathrm{mg} \mathrm{g}^{-1} \mathrm{FW}\right)$ in the leaves of 30-day old plants of $B$. juncea grown in soil amended with $\mathrm{Cu}(\mathrm{II})$ solution before sowing.

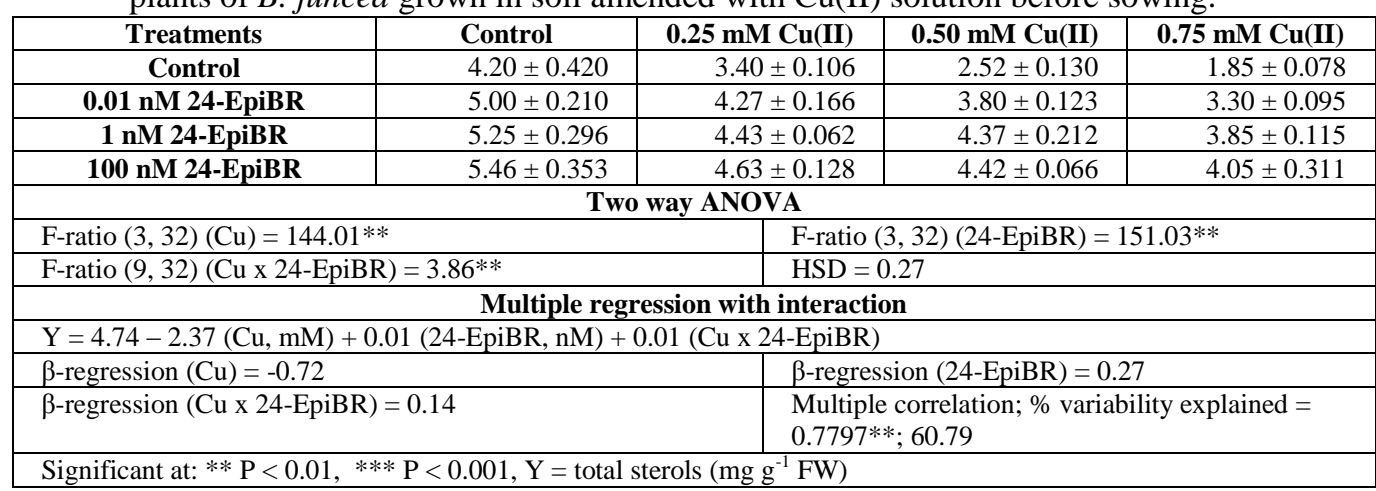

Table 10. Effect of seed pre-soaking with 24-EpiBR on esterified sterols ( $\mathrm{mg} \mathrm{g}^{-1} \mathrm{FW}$ ) in the leaves of 30-day old plants of $B$. juncea grown in soil amended with $\mathrm{Cu}(\mathrm{II})$ solution before sowing.

\begin{tabular}{|c|c|c|c|c|}
\hline Treatments & Control & $0.25 \mathrm{mM} \mathrm{Cu}(\mathrm{II})$ & 0.50 mM Cu(II) & $0.75 \mathrm{mM} \mathrm{Cu}(\mathrm{II})$ \\
\hline Control & $1.28 \pm 0.066$ & $1.02 \pm 0.026$ & $0.74 \pm 0.017$ & $0.58 \pm 0.017$ \\
\hline 0.01 nM 24-EpiBR & $1.36 \pm 0.035$ & $1.13 \pm 0.072$ & $0.89 \pm 0.095$ & $0.72 \pm 0.044$ \\
\hline 1 nM 24-EpiBR & $1.41 \pm 0.056$ & $1.20 \pm 0.066$ & $1.12 \pm 0.056$ & $0.86 \pm 0.036$ \\
\hline 100 nM 24-EpiBR & $1.41 \pm 0.036$ & $1.18 \pm 0.062$ & $1.02 \pm 0.066$ & $0.87 \pm 0.095$ \\
\hline \multicolumn{5}{|c|}{ Two way ANOVA } \\
\hline \multirow{2}{*}{\multicolumn{3}{|c|}{$\begin{array}{l}\text { F-ratio }(3,32)(\mathrm{Cu})=243.47 * * \\
\text { F-ratio }(9,32)(\mathrm{Cu} \times 24-\mathrm{EpiBR})=239 *\end{array}$}} & \multicolumn{2}{|c|}{ F-ratio $(3,32)(24$-EpiBR $)=43.21 * *$} \\
\hline & $=2.39 *$ & & $\mathrm{HSD}=0.08$ & \\
\hline \multicolumn{5}{|c|}{ Multiple regression with interaction } \\
\hline \multicolumn{5}{|c|}{$\mathrm{Y}=1.34-0.84(\mathrm{Cu}, \mathrm{mM})+0.001(24-\mathrm{EpiBR}, \mathrm{nM})+0.001(\mathrm{Cu} \times 24-\mathrm{EpiBR})$} \\
\hline \multicolumn{3}{|c|}{$\beta$-regression $(\mathrm{Cu})=-0.94$} & \multicolumn{2}{|c|}{$\beta$-regression $(24-$ EpiBR $)=0.08$} \\
\hline \multicolumn{3}{|c|}{$\beta$-regression $(\mathrm{Cu} \times 24-E p i B R)=0.11$} & \multicolumn{2}{|c|}{$\begin{array}{l}\text { Multiple correlation; } \% \text { variability } \\
\text { explained }=0.9262 * * * ; 85.78\end{array}$} \\
\hline
\end{tabular}

Table 11. Effect of seed pre-soaking with 24-EpiBR on glucose $\left(\mathrm{mg} \mathrm{g}^{-1} \mathrm{FW}\right)$ in the leaves of 30-day old plants of $B$. juncea grown in soil amended with $\mathrm{Cu}(\mathrm{II})$ solution before sowing.

\begin{tabular}{|c|c|c|c|c|}
\hline Treatments & Control & $\begin{array}{c}0.25 \mathrm{mM} \\
\mathrm{Cu}(\mathrm{II})\end{array}$ & $0.50 \mathrm{mM} \mathrm{Cu}(\mathrm{II})$ & $0.75 \mathrm{mM} \mathrm{Cu}(\mathrm{II})$ \\
\hline Control & $0.81 \pm 0.020$ & $0.71 \pm 0.066$ & $0.55 \pm 0.036$ & $0.48 \pm 0.010$ \\
\hline 0.01 nM 24-EpiBR & $0.86 \pm 0.010$ & $0.74 \pm 0.040$ & $0.71 \pm 0.026$ & $0.61 \pm 0.070$ \\
\hline 1 nM 24-EpiBR & $0.89 \pm 0.017$ & $0.80 \pm 0.090$ & $0.73 \pm 0.017$ & $0.63 \pm 0.020$ \\
\hline 100 nM 24-EpiBR & $0.94 \pm 0.026$ & $0.86 \pm 0.026$ & $0.84 \pm 0.010$ & $0.71 \pm 0.044$ \\
\hline \multicolumn{5}{|c|}{ Two way ANOVA } \\
\hline \multicolumn{3}{|c|}{ F-ratio $(3,32)(\mathrm{Cu})=94.47 * *$} & \multicolumn{2}{|c|}{ F-ratio $(3,32)(24-E p i B R)=50.92 * *$} \\
\hline \multicolumn{3}{|c|}{ F-ratio $(9,32)(\mathrm{Cu} \times 24$-EpiBR $)=2.04$} & \multicolumn{2}{|l|}{$\mathrm{HSD}=0.05$} \\
\hline \multicolumn{5}{|c|}{ Multiple regression with interaction } \\
\hline \multicolumn{5}{|c|}{$\mathrm{Y}=0.85-0.37(\mathrm{Cu}, \mathrm{mM})+0.001(24-E p i B R, \mathrm{nM})+0.001(\mathrm{Cu} \times 24-E p i B R)$} \\
\hline \multicolumn{3}{|c|}{$\beta$-regression $(\mathrm{Cu})=-0.84$} & \multicolumn{2}{|c|}{$\beta$-regression (24-EpiBR) $=0.33$} \\
\hline \multicolumn{3}{|c|}{$\beta$-regression $(\mathrm{Cu} \times 24-\mathrm{EpiBR})=0.15$} & \multicolumn{2}{|c|}{$\begin{array}{l}\text { Multiple correlation; \% variability } \\
\text { explained }=0.9106^{* * *} ; 82.92\end{array}$} \\
\hline
\end{tabular}


24-epibrassinolide mediated regulation of endogenous contents of auxins, abscisic acid, lipids ...

Table 12. Effect of seed pre-soaking with 24-EpiBR on fructose $\left(\mathrm{mg} \mathrm{g}^{-1} \mathrm{FW}\right)$ in the leaves of 30-day old plants of $B$. juncea grown in soil amended with $\mathrm{Cu}(\mathrm{II})$ solution before sowing.

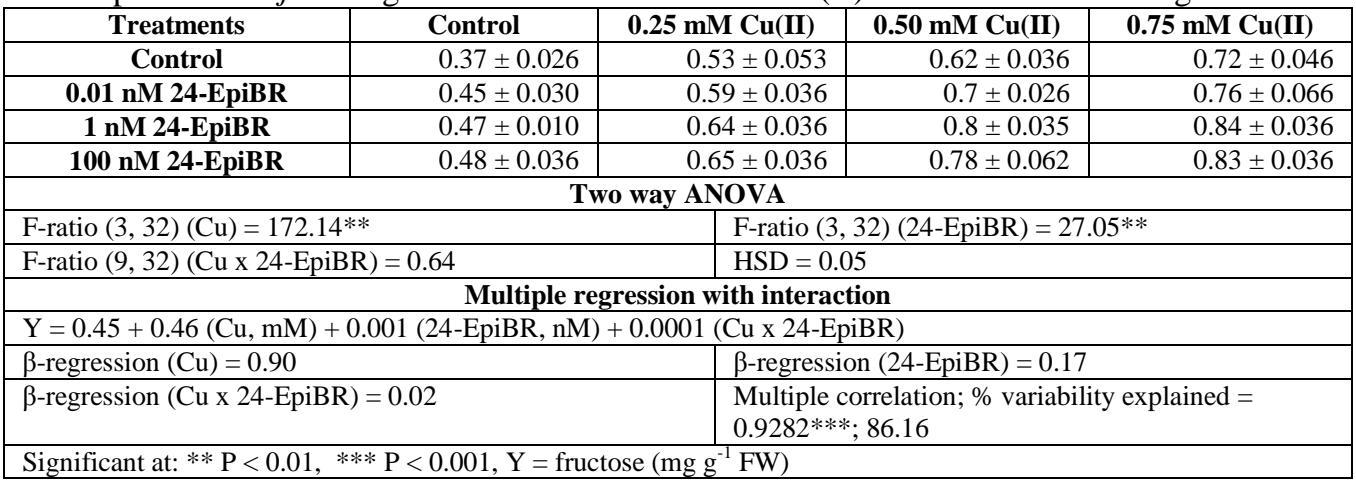

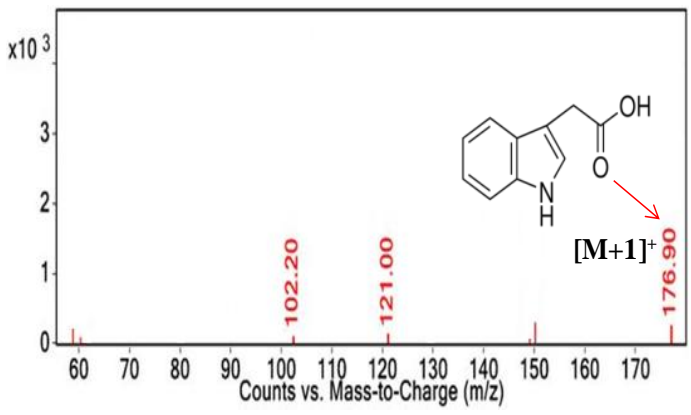

Control

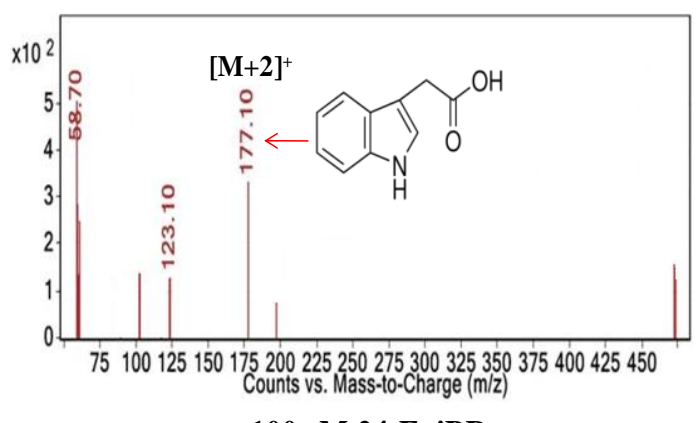

$100 \mathrm{nM}$ 24-EpiBR

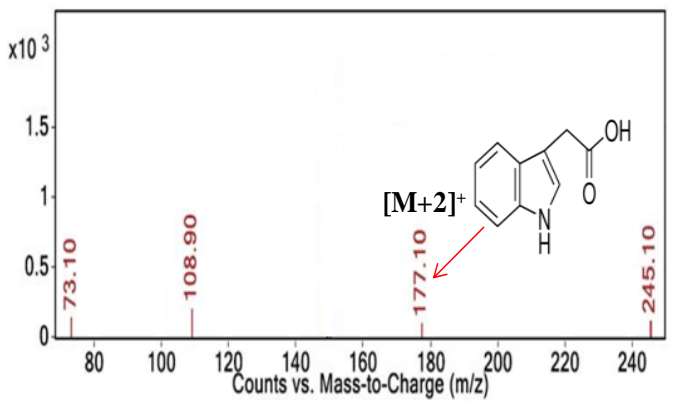

$0.50 \mathrm{mM} \mathrm{Cu}(\mathrm{II})$

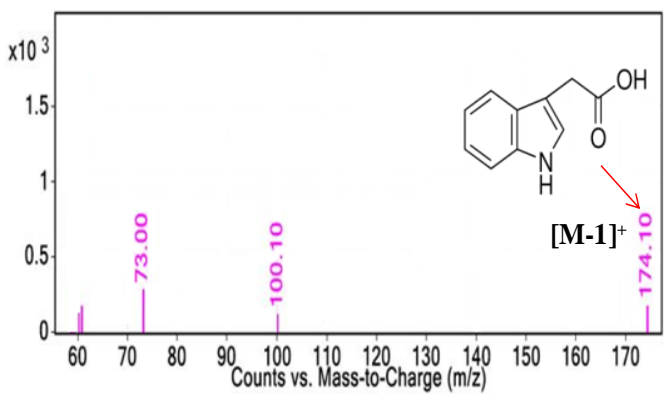

$100 \mathrm{nM}$ 24-EpiBR + 0.50 mM Cu(II)

Fig. 1. Effect of seed pre-soaking with 24-EpiBR on IAA (relative abundance) in the leaves of 30-day old plants of $B$. juncea grown in soil amended with $\mathrm{Cu}(\mathrm{II})$ solution before sowing. 


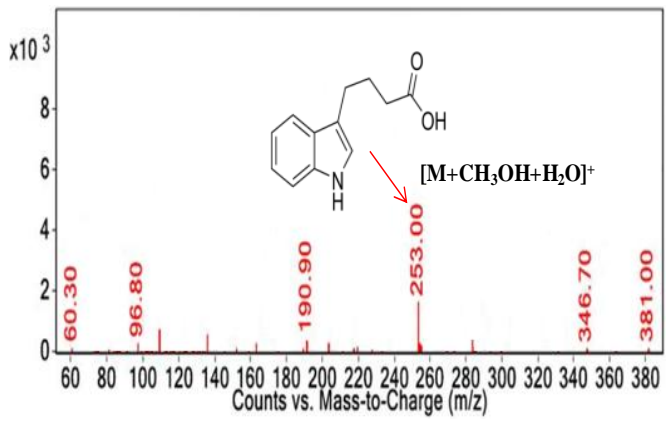

Control

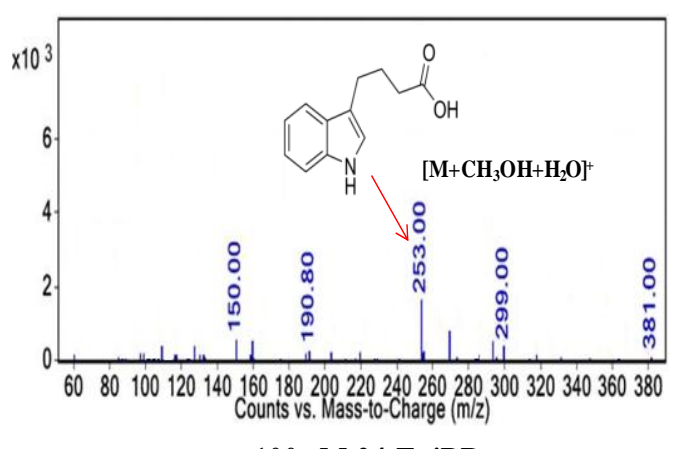

$100 \mathrm{nM}$ 24-EpiBR

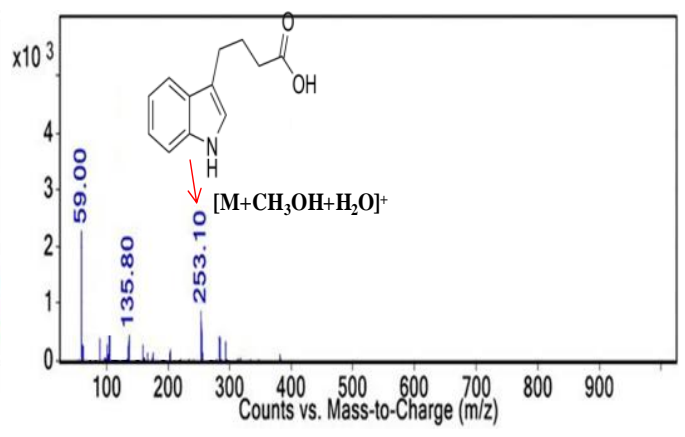

$0.50 \mathrm{mM} \mathrm{Cu}(\mathrm{II})$

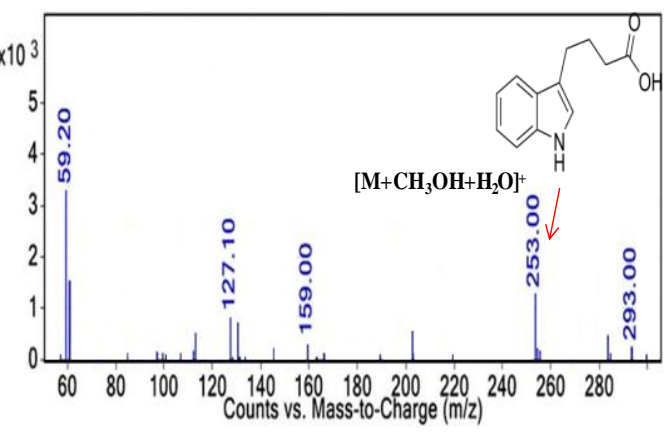

$100 \mathrm{nM}$ 24-EpiBR + $0.50 \mathrm{mM} \mathrm{Cu}(\mathrm{II})$

Fig. 2. Effect of seed pre-soaking with 24-EpiBR on IBA (relative abundance) in the leaves of 30-day old plants of $B$. juncea grown in soil amended with $\mathrm{Cu}(\mathrm{II})$ solution before sowing.
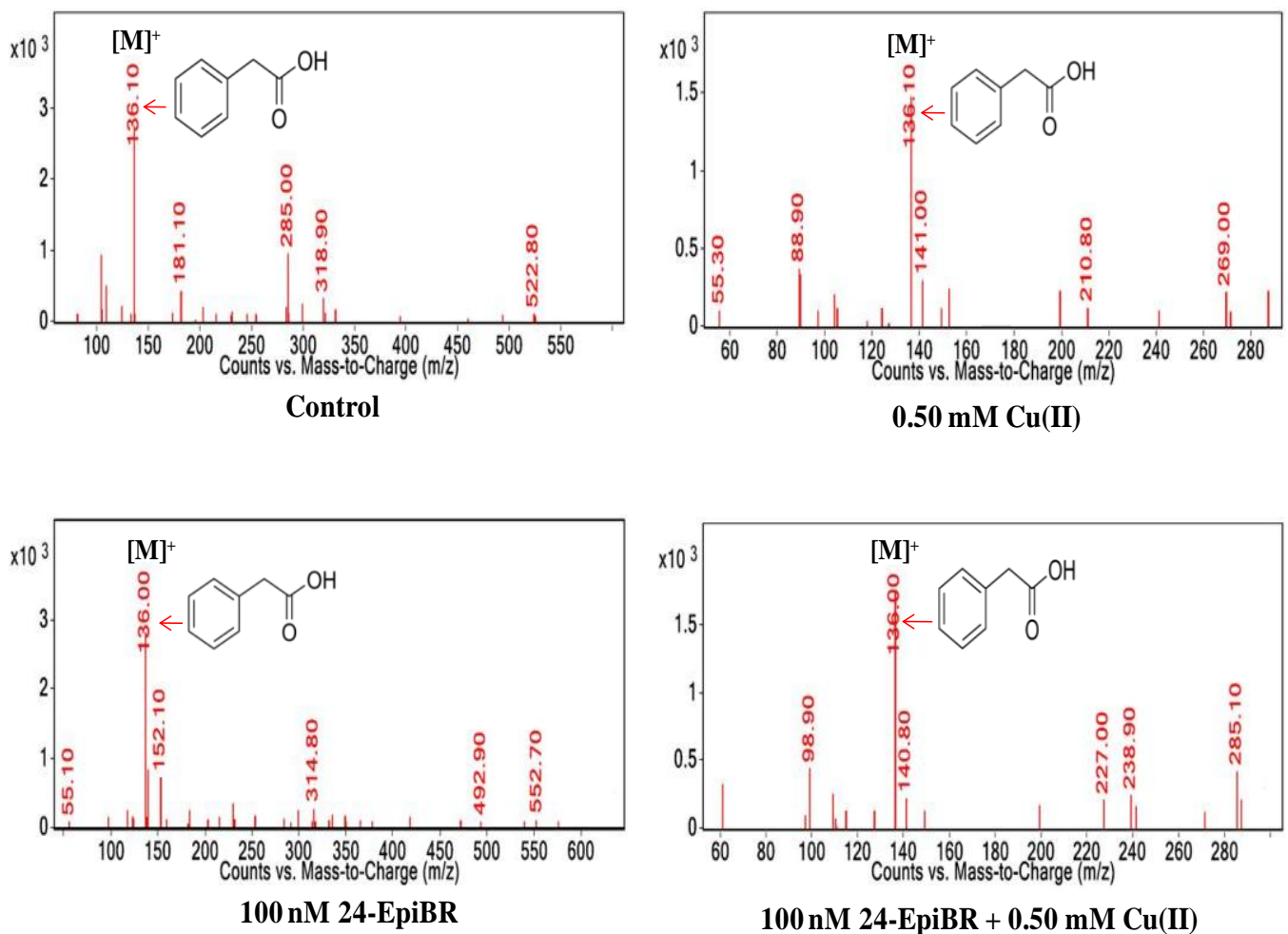

Fig. 3. Effect of seed pre-soaking with 24-EpiBR on PAA (relative abundance) in the leaves of 30-day old plants of $B$. juncea grown in soil amended with $\mathrm{Cu}(\mathrm{II})$ solution before sowing. 


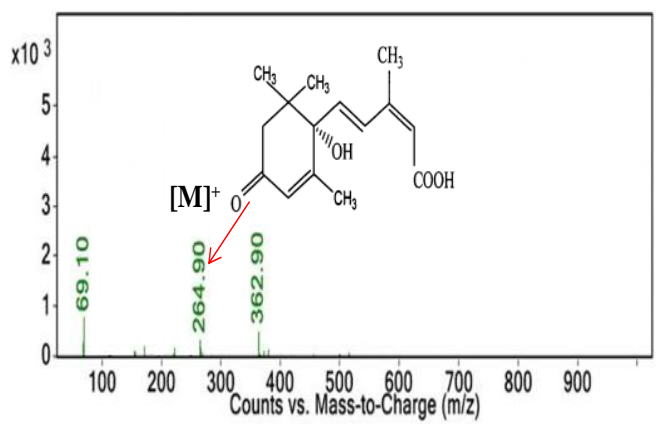

Control

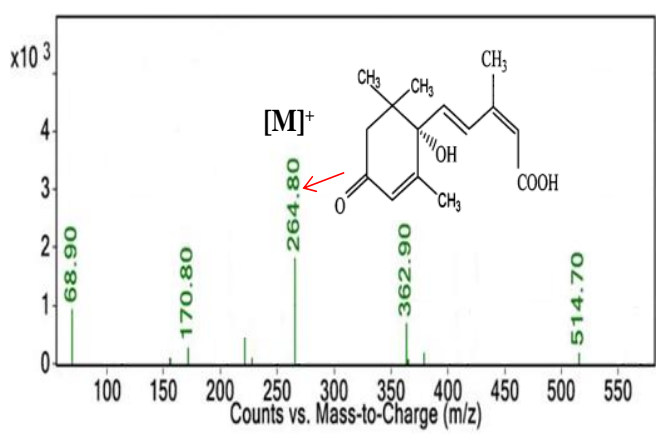

$100 \mathrm{nM}$ 24-EpiBR
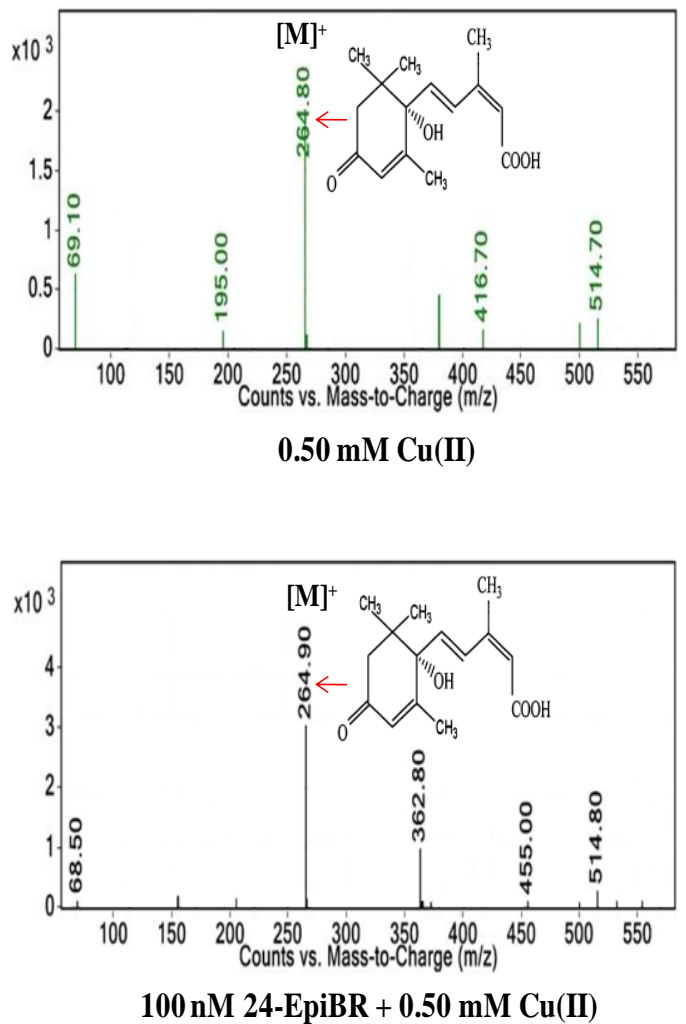

Fig. 4. Effect of seed pre-soaking with 24-EpiBR on abscisic acid (relative abundance) in the leaves of 30day old plants of $B$. juncea grown in soil amended with $\mathrm{Cu}(\mathrm{II})$ solution before sowing.

\section{Conclusion}

$\mathrm{Cu}$ stress affects the plant growth and metabolism. We noticed a reduction in plant biomass and various biomolecules such as sugars (glucose and sucrose) and lipids (phospholipids, total sterols and esterified sterols) and an enhancement in MDA content under $\mathrm{Cu}$ (II) stress. However, the supplementation of soil $\mathrm{Cu}$ (II) treatment with 24-EpiBR seed pre-soaking treatment increased the plant biomass by increasing the endogenous contents of auxins (IAA, IBA and PAA) and also improved the contents of the sugars and the lipids and reduced the content of MDA. 24-EpiBR crosstalk with abscisic acid was also evident as its co-application with $\mathrm{Cu}(\mathrm{II})$ enhanced abscisic acid content and increased the plants ability to cope with the $\mathrm{Cu}(\mathrm{II})$ stress.

\section{Acknowledgement}

Financial assistance from Department of Science and Technology (DST), Ministry of Science and Technology, Government of India, New Delhi, India is duly acknowledged.

\section{References}

[1]. F. Vinit-Dunand, D. Epron, B. Alaoui-Sosse, and P. M. Badot, Effects of copper on growth and on photosynthesis of mature and expanding leaves in cucumber plants. Plant Science, 2002, 163, 53-58.

[2]. R. A. Wuana, and F. E. Okieimen, Heavy metals in contaminated soils: A review of sources, chemistry, risks and best available strategies for remediation. ISRN Ecology, 2011, Doi:10.5402/2011/402647.

[3]. S. Rahoui, A. Chaoui, and E. E. Ferjani, Reserve mobilization disorder in germinating seeds of Vicia faba L. exposed to cadmium. Journal of Plant Nutrition, 2010, 33, 809-817.

[4]. J. C. Fernandes, and F. S. Henriques, Biochemical, physiological, and structural effects of excess copper in plants, Botanical Review, 1991, 57, 246-273.

[5]. A. W. Woodward, and B. Bartel, Auxin: regulation, action, and interaction. Annals of Botany, 2005, 95, 707-735.

[6]. S. Vanneste, and J. Friml, Auxin: a trigger for change in plant development. Cell, 2009, 136, 1005-1016.

[7]. W. -H. Hu, X. -H. Yan, Y. -A. Xiao, J. -J. Zeng, H. -J. Qi, and J. O. Ogweno, 24-epibrassinosteroid alleviate drought-induced inhibition of photosynthesis in Capsicum annuum. Scientia Horticulturae, 2013, 150, 232-237.

[8]. V. B. Tognetti. O. Van Aken, K. Morreel, K. Vandenbroucke, B. van de Cotte, I. De Clercq, S. Chiwocha, R. Fenske, E. Prinsen, W. Boerian, B. Genty, K. A. Stubbs, D. Inze, and F. Van Breuseqem, Perturbation in indole-3-butyric acid homeostasis by the UDP glucosyltransferase UTG74E2 modulates Arabidopsis architecture and water stress tolerance. Plant Cell, 2010, 22, 2660-2679.

[9]. Y. Liu, H. Jiang, Z. Zhao, and L. An, Abscisic acid is involved in brassinosteroids-induced chilling tolerance in the suspension cultured cells from Chorispora bungeana. Journal of Plant Physiology, 2011, 168, 853-862.

[10]. T. -M. Lee, H. -S. Lur, and C. Chu, Role of abscisic acid in chilling tolerance of rice (Oryza sativa L.) seedlings. I. Endogenous abscisic acid levels. Plant Cell and Environment, 1993, 16, 481-490.

[11]. O, Munzuroglu, F. K. Zengin, and Z. Yahyagil, The abscisic acid levels of wheat (Triticum aestivum L. cv. Çakmak 79) seeds that were germinated under heavy metal $\left(\mathrm{Hg}^{++}, \mathrm{Cd}^{++}, \mathrm{Cu}^{++}\right)$stress. Gazi University Journal of Science. 2008, 21, 1-7. 
[12]. S. Monni, C. Uhlig, O. Junttila, E. Hansen, and J. Hynynen, Chemical composition and ecophysiological responses of Empetrum nigrum to above ground element application. Environmental Pollution, 2001, 112, 417-426.

[13]. Y. T. Hsu, and C. H. Kao, Role of abscisic acid in cadmium tolerance of rice Oryza sativa L.) seedling. Plant Cell and Environment, 2003, 26, 867-874.

[14]. M. N. Vazquez, Y. R. Guerrero, L. M. Gonzalez, and W. T. D. L. Noval, Brassinosteroids and plant responses to heavy metal stress. An overview. Open Journal of Metal, 2013, 3, 34-41.

[15]. R. L. Heath, and L. Packer, Photoperoxidation in isolated chloroplasts. I. Kinetics and stoichiometry of fatty acid peroxidation. Archives of Biochemistry and Biophysics, 1968, 125, 189-198.

[16]. M. Kates, Plant phospholipids and glycolipids. Advances in Lipid Research, 1970, 8, 225-265.

[17]. B. N. Ames, and D. T. Dubin, The role of polyamines in the neutralization of bacteriophage deoxyribonucleic acid. Journal of Biological Chemistry, 1960, 235, 769-775.

[18]. W. M. Sperry, and M. Webb, A revision of the Schoenheimer-Sperry method for cholesterol determination. Journal of Biological Chemistry, 1950, 187, 97-106.

[19]. N. Singh, and R. Luthra, Sucrose metabolism and essential oil accumulation during lemongrass (Cymbopogon flexuosus Stapf.) leaf development. Plant Science, 1988, 57, 127-133.

[20]. S. Gascon, and J. O. Lampen, Purification of the internal invertase of yeast. Journal of Biological Chemistry, 1968, 243, 1567-1572

[21]. J. H. Roe, A colorimetric method for the determination of fructose in blood and urine. Journal of Biological Chemistry, 1934, 107, $15-22$.

[22]. K. Banerjee, and S. Kulkarni, Agilent 6530 accurate-mass Q-TOF LC/MS system with agilent 1290 infinity LC for multi plant growth regulator analysis from grapes. Agilent Technologies, Inc., USA, 2011, 5990-7185EN.

[23]. S. Kiran, Ozkay, F., S. Kusvuran, and S. Ellialtioglu, Effects of copper stress on the growth of eggplant seedlings, International Conference on Advances in Plant Sciences (ICAPS 2012) November 14-18, Empress Hotel, Chiang Mai, Thailand, 2012.

[24]. S. Gvozdenac, D. Indic, S. Vukovic, and V. Bursic, $\mathrm{Cu}$ and $\mathrm{Cd}$ tolerance of barley and white mustard: Potential indicators of water contamination with these heavy metals. Research Journal of Agricultural Science, 2013, 45, 118-126.

[25]. H. Ashagre, M. Shelema, R. Kedir, and S. Ebsa, Seed germination and seedling growth of haricot bean (Phaseolus vulgaris L.) cultivars as influenced by copper sulphate. World Journal of Agricultural Sciences, 2013, 1, 312-317.

[26]. S. P. Choudhary, R. Bhardwaj, B. D. Gupta, P. Dutt, R. K. Gupta, S. Biondid, and M. Kanwar, Epibrassinolide induces changes in indole-3-acetic acid, abscisic acid and polyamine concentrations and enhances antioxidant potential of radish seedlings under copper stress. Physiologia Plantarum, 2010, 140, 280-296.

[27]. M. Elobeid, C. Gobel, I. Feussner, and A. Polle, Cadmium interferes with auxin physiology and lignification in Poplar. Journal of Experimental Botany, 2012, 63, 1413-1421.

[28]. A. Chaoui, and E. E. Ferjani, Effects of cadmium and copper on antioxidant capacities, lignification and auxin degradation in leaves of pea (Pisum sativum L.) seedlings. Comptes Rendus Biologies, 2005, 328, 23-31.

[29]. A. Peto, N. Lehotai, J. Lozano-Juste, J. Leon, I. Tari, L. Erdei, and Z. Kolbert, Involvement of nitric oxide and auxin in signal transduction of copper-induced morphological responses in Arabidopsis seedlings. Annals of Botany, 2011, 108, 449-457.

[30]. Z. Kolbert, A. Peto, N. Lehotai, G. Feigl, and L. Erdei, Long-term copper $\left(\mathrm{Cu}^{2+}\right)$ exposure impacts on auxin, nitric oxide (NO) metabolism and morphology of Arabidopsis thaliana L. Plant Growth Regulation, 2012, 68, 151-159.

[31]. W. Chouychai, Effect of some plant growth regulators on lindane and alpha-endosulfan toxicity to Brassica chinensis, Journal of Environmental Biology, 2012, 33, 811-816.

[32]. A. H. Nassar, Effect of some copper compounds on rhizogenesis of micropropagated banana shoots. International Journal of Agriculture and Biology, 2004, 6, 552-556.

[33]. J. L. Nemhauser, T. C. Mockler, and J. Chory, Interdependency of brassinosteroid and auxin signaling in Arabidopsis. PLoS Biology, 2004, 2: e258. Doi: 10.1371/journal.pbio.0020258.

[34]. N. B. Mandava, Plant growth-promoting brassinosteroids. Annual Review of Plant Physiology and Plant Molecular Biology, 1988, $39,23-52$

[35]. B. Usha, G. Venkataraman, and A. Parida, Heavy metal and abiotic stress inducible metallothionein isoforms from Prosopis juliflora (SW) D.C. show differences in binding to heavy metals in vitro. Molecular Genetics and Genomics, 2009, 281, 99-108.

[36]. A. Bajguz, Isolation and characterization of brassinosteroids from algal cultures of Chlorella vulgaris Beijerinck (Trebouxiophyceae). Journal of Plant Physiology, 2009, 166, 1946-1949.

[37]. G. -F. Yuan, C. -G. Jia, Z. Li, B. Sun, L. -P. Zhang, N. Liu, and Q. -M. Wang, Effect of brassinosteroids on drought resistance and abscisic acid concentration in tomato under water stress. Scientia Horticulturae, 2010, 126, 103-108.

[38]. P. M. Gomes, M. Carvalho, T. C. L. L. S. E. Marques, D. M. Duarte, C. D. O. G. Nogueira, A. M. Soares, and Q. D. S. Garcia, Arsenic-sensitivity in Anadenanthera peregrina due to arsenic-induced lipid peroxidation. International Journal of Applied Science and Technology, 2012, 2, 55-63.

[39]. H. Kappus, Lipid peroxidation: Mechanisms, analysis, enzymology and biological relevance, In: H. Sies (Ed.), Oxidative Stress, (Academic Press, London, 1985) 273-310.

[40]. W. Maksymiec, Effect of $\mathrm{Cu}$ on cellular processes in higher plants. Photosynthetica, 1997, 34, 321-342.

[41]. N. Arora, R. Bhardwaj, P. Sharma, H. K. Arora, and P. Arora, Amelioration of zinc toxicity by 28-homobrassinolide in Zea mays L. Canadian Journal of Pure and Applied Sciences, 2008, 2, 503-509.

[42]. F. Ozdemir, M. Bor, T. Demiral, and I. Turkan, Effects of 24-epibrassinolide on seed germination, seedling growth, lipid peroxidation, proline content and antioxidative system of rice (Oryza sativa L.) under salinity stress. Plant Growth Regulation, $2004,42,203-211$.

[43]. A. -B. M. Al-Hakimi, and A. M. Hamada, Ascorbic acid, thiamine or salicylic acid induced changes in some physiological parameters in wheat grown under copper stress. Plant Protection Science, 2011, 47, 92-108.

[44]. L. E. Hernandez, and D. T. Cooke, Modification of the root plasma membrane lipid composition of cadmium-treated Pisum sativum. Journal of Experimental Botany, 1997, 48, 1375-1381.

[45]. A. A. Morsy, K. H. A. Salama, H. A. Kamel, and M. M. F. Mansour, Effect of heavy metals on plasma membrane lipids and antioxidant enzymes of Zygophyllum species, Eurasian Journal of Biosciences, 2012, 6, 1-10.

[46]. H. Svenningsson, and C. Lilijenberg, Membrane lipid changes in root cells of rape (Brassica napus) as a function of water-deficit stress. Physiologia Plantarum, 1986, 68, 53-58.

[47]. R. Azmat, and S. Riaz, The inhibition of polymerization of glucose in carbohydrate under cu stress in Vigna radiate. Pakistan Journal of Botany, 2012, 44, 95-98.

[48]. S. Verma, and R. S. Dubey, Effect of Cadmium on soluble sugars and enzymes of their metabolism in rice. Biologia Plantarum, $2001,44,117-123$ 
24-epibrassinolide mediated regulation of endogenous contents of auxins, abscisic acid, lipids ...

[49]. S. Danai-Tambhale, V. Kumar, and V. Shriram, Differential response of two scented Indica rice (Oryza sativa) cultivars under salt stress, Journal of Stress Physiology and Biochemistry, 2011, 7, 387-397.

[50]. J. Q. Yu, L. F. Huang, W. H. Hu, Y. H. Zhou, W. H. Mao, S. F. Ye, and S. Nogues, A role for brassinosteroids in the regulation of photosynthesis in Cucumis sativus. Journal of Experimental Botany, 2004, 55, 1135-1143. 